\title{
Penggunaan Jaringan Syaraf Tiruanuntuk Membaca Karakter pada Formulir Nilai Mata Kuliah
}

\author{
La Surimi, Hendra, Diaraya*
}

\begin{abstract}
Abstrak
Jaringan syaraf tiruan (JST) telah banyak diaplikasikan dalam berbagai bidang terutama dalam pengenalan pola. Kemampuan JST untuk mentolerir perbedaan antara data pelatihan dan data yang akan diolah diharapkan dapat diaplikasikan untuk mengenali pola karakter yang ada pada lembar formulir nilai matakuliah. Pemrosesan awal citra blanko dibutuhkan sebelum menggunakan JST, pemrosesan yang digunakan adalah traceholding, noise eliminator, thinning, segmentasi dan normalisasi karakter. Hasil penelitian menunjukkan penggunakaan128 node layer tersembunyi pada JST memberikan hasil terbaik dimana 4 buah formulir nilai dapat dikenali dengan baik tanpa kesalahan. Kesalahan pengenalan yang ada masih dapat dihilangkan dengan menambahkan data pembelajaran pada sistem.
\end{abstract}

Kata Kunci: Pengenalan karakter, Backpropagation, citra digital.

\section{Pendahuluan}

Kemajuan teknologi membuat sebuah perangkat komputer memiliki kemampuan komputasi yang tinggi untuk meningkatkan kinerja dalam pengolahan data menjadi informasi. Namun hal ini tidak diimbangi dengan kemampuan manusia dalam memasukan data secara manual ke dalam komputer agar dapat diolah lebih lanjut. Proses penginputan nilai mata kuliah ke dalam database, umumnya masih menerapkan cara manual, sehingga keakuratan data yang diinput sangat tergantung pada ketelitian penginput. Terbatasnya kemampuan penginput dan banyaknya data yang harus dimasukan menyebabkan seringnya terjadi kesalahan penginputan.

Untuk itu dipandang perlu untuk menemukan solusi yang lebih baik sehingga proses penginputan data tersebut lebih cepat dan lebih akurat. Solusi yang ditawarkan untuk menyelesaikan masalah ini adalah membangun software khusus yang mampu membaca langsung data pada formulir nilai dan data tersebut langsung disimpan kedalam komputer tanpa campur tangan manusia lagi.

Untuk membangun sistem seperti itu dibutuhkan sistem pengenalan huruf (Character Recognition System) sehingga mampu mengenali karakter yang terdapat pada formulir nilai. Teknik yang sering digunakan untuk membangun sistem pengenal huruf adalah Jaringan Syaraf Tiruan atau yang sering dikenal dengan JST (Kamruzzaman dkk., 1998). Teknik ini menggunakan pendekatan cara kerja otak manusia dalam menyelesaiankan masalah. Dalam hal ini pola karakter yang terdapat pada suatu formulir nilai matakuliah akan diberikan pada JST sebagai data pembelajaran. Sehingga diharapkan JST dapat mengenali karakter yang terdapat pada formulir nilai mata kuliah yang lain.

\footnotetext{
* Jurusan Matematika, Fakultas Matematika dan Ilmu Pengetahuan Alam, Universitas Hasanuddin
} 


\section{Pengolahan Citra}

Pengolahan citra meliputi perbaikan atau memodifikasi citra yang dilakukan untuk meningkatkan kualitas penampakan atau untuk menonjolkan beberapa aspek informasi yang terkandung di dalam citra, elemen di dalam citra perlu dikelompokkan, dicocokkan atau diukur dan sebagian citra perlu digabung dengan bagian citra yang lain (Lyanthi, 2003). Adapun metode pengolahan citra yang digunakan pada penelitian ini adalah sebagai berikut:

\section{a. Greyscale}

Dengan menggunakan model warna RGB, gambar yang berwarna dapat diubah menjadi gambar yang terdiri dari warna putih dan gradiasi warna hitam yang biasa disebut citra grayscale. Untuk mengubah RGB menjadi grayscale dapat digunakan rumus sebagai berikut:

$$
\text { greyscale }=0.299 R+0.587 G+0.114 B
$$

atau

$$
\text { greyscale }=0.333 R+0.333 G+0.333 B
$$

Persamaan yang umum digunakan adalah persamaan (2).

\section{b. Thresholding}

Thresholding adalah proses mengubah citra menjadi citra biner. Citra biner adalah citra yang memiliki dua nilai tingkat keabuan yaitu hitam dan putih. Secara umum proses binersisasi citra grayscale untuk menghasilkan citra biner adalah

$$
g(x, y)=\left\{\begin{array}{l}
1, \text { jika } f(x, y)>T \\
0, \text { jika } f(x, y) \leq T
\end{array}\right.
$$

dengan $g(x, y)$ adalah citra biner dari citra grayscale $f(x, y)$ dan $T$ menyatakan nilai ambang (Darmaputra,2003).

\section{c. Filter Noise Eliminator}

Filter Noise Eliminator adalah proses penghapusan noise yang terdapat pada citra. Untuk menghilangkan nosie pada citra digunakan spatial filter 3x3 (Gambar 1), dengan aturan sebagai berikut

$$
\text { Pixel }=\left\{\begin{array}{l}
1, \text { jika } f(x)>10 \\
0, \text { jika } f(x) \leq 10
\end{array}\right.
$$

dimana $f(x)$ adalah hasil perkalian secara konvolusi spatial filter di atas terhadap piksel yang ditinjau.

\begin{tabular}{|l|l|l|}
\hline 2 & 2 & 2 \\
\hline 2 & 5 & 2 \\
\hline 2 & 2 & 2 \\
\hline
\end{tabular}

\section{d. Thining}

Gambar 1. Filter untuk Menghilangkan Noise. 
Thinning digunakan untuk merapikan hasil dari deteksi sisi dengan menipiskan semua garis sampai lebarnya hanya satu piksel. Algoritma Thining yang digunakan pada penelitian ini adalah algoritma Stentiford.

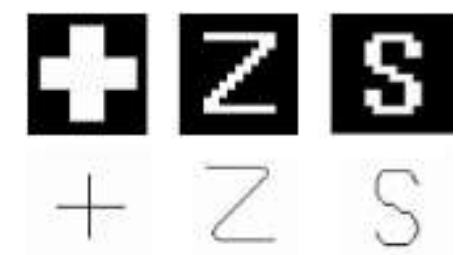

Gambar 2. Proses Thining Menggunakan Algoritma Stentiford.

\section{e. Segmentasi}

Segmentasi citra pada penelitian ini bertujuan untuk memisahkan huruf per huruf yang akan dikenali dari sebuah citra formulir nilai. Proses segmentasi menggunakan bantuan histogram citra. Histogram menyimpan informasi jumlah piksel menurut derajat keabuan. Segmentasi dapat digunakan untuk mengidentifikasi objek dalam citra dengan asumsi beda derajat keabuan maka objeknya juga berbeda (Wibowo dkk., 2004).

\section{f. JST Backpropagation}

Seperti halnya model JST yang lain, Backpropagation melatih jaringan untuk mendapatkan keseimbangan antara kemampuan jaringan Untuk mengenali pola yang digunakan selama pelatihan serta kemampuan jaringan untuk memberikan respon yang benar terhadap pola masukan yang serupa (tapi tidak sama) dengan pola yang dipakai selama pelatihan.

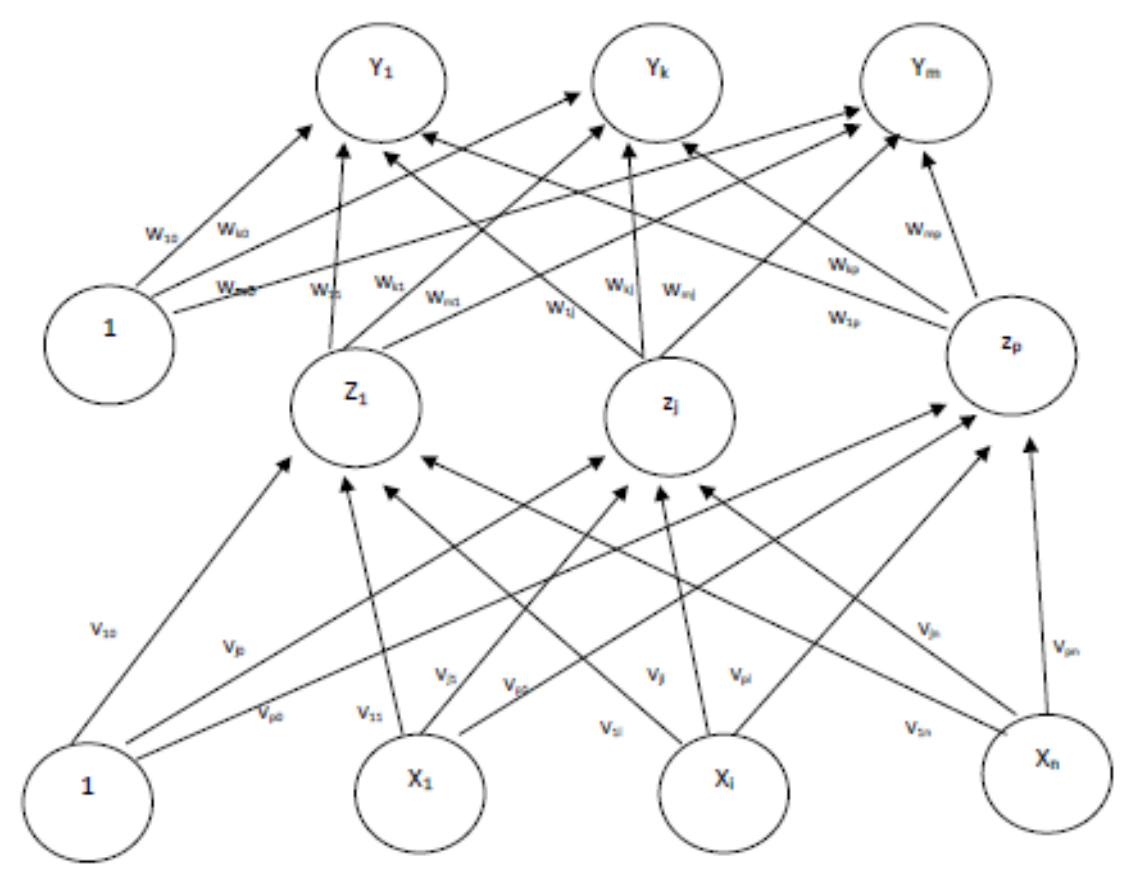

Gambar 3. Arsitektur JST Backpropagation.

Pada intinya, pelatihan dengan metode backpropagation terdiri dari tiga langkah, yaitu:

1. Data dimasukkan ke input jaringan (feedforward) 


\section{La Surimi, Hendra, Diaraya}

2. Perhitungan dan propagasi balik dari error yang bersangkutan

3. Pembaharuan (adjustment) bobot dan bias (Siang, 2005).

\section{Implementasi}

Untuk membangun sistem pengenalan karakter dengan jaringan syaraf tiruan dibutuhkan tiga buah sistem yang terdiri dari sistem pendefinisian, sistem pembelajaran dan sistem implementasi. Ketiga sistem ini merupakan satu kesatuan dalam pengenalan karakter.

\subsection{Sistem Pendefinisian}

Sistem pendefinisian digunakan untuk mendefinisikan data belajar yang digunakan untuk memberikan pengetahuan kepada sistem tentang ciri-ciri karakter yang akan digunakan. Sistem ini memiliki struktur desain sebagai berikut.

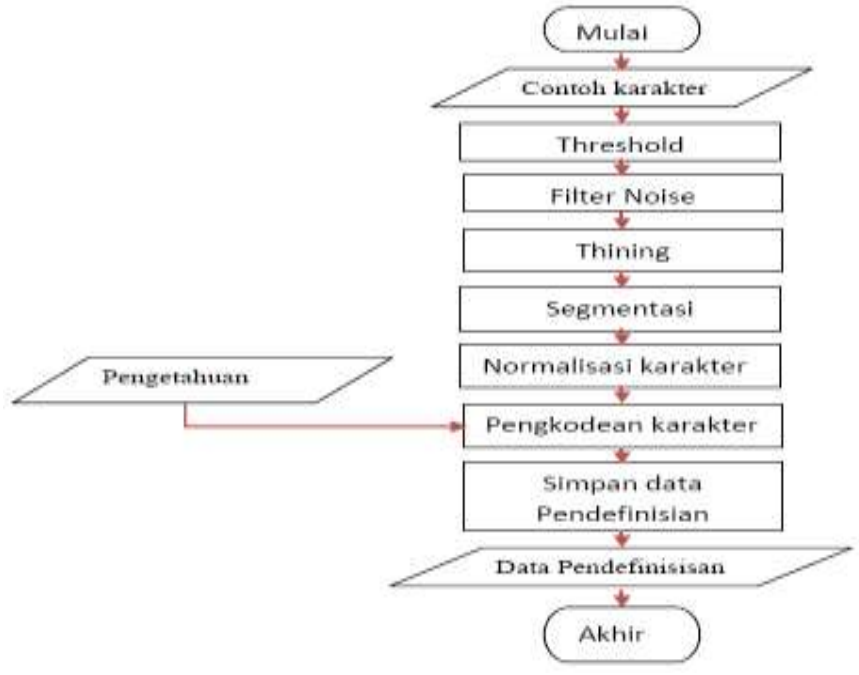

Gambar 4. Struktur Kerja Sistem Pendefinisian.

Pada sistem pendefinisian karakter input pembelajaran yang diberikan adalah contoh karakter, yaitu daftar seluruh karakter yang digunakan dalam mendefinisikan semester, kode matakuliah, program studi, dan nim mahasiswa. Jadi tidak seluruh karakter yang ada digunakan sebagai bahan pembelajaran. Karakter-karakter yang digunakan adalah 0,1,2,3,4,5,6,7,8,9,A,B,C,D,E,F,G,H,I,J,K,L,M, dan N. Pada sistem pendefinisian karakter tulisan tangan, input pembelajaran yang diberikan adalah contoh karakter yang digunakan untuk mendefinisikan nilai mata kuliah yaitu A,B,C,D,E, dan T.

Pada proses normalisasi karakter, awalnya citra karakter hasil operasi segmentasi memiliki ukuran yang berbeda-beda, sehingga hal ini akan mempersulit penentuan jumlah node input jaringan saraf tiruan yang akan digunakan kelak. Untuk itu perlu dilakukan normalisasi karakter yaitu dengan menyeragamankan ukuran semua karakter. Dalam penelitian ini ukuran dari semua karakter ditrasformasi ke ukuran 9x9 piksel.

Setelah melalui proses normalisasi maka piksel dari masing-masing karakter tersebut akan dikonversi ke kode biner sebanyak 81 digit, yang selanjutnya akan menjadi data input pada node input jaringan saraf tiruan.

Untuk memberikan pengetahuan pada sistem bahwa kode biner karakter yang diberikan adalah karakter tertentu, maka sistem juga harus diberitahukan tentang karakter tersebut, dimana 


\section{La Surimi, Hendra, Diaraya}

karakter itu dinyatakan dalam kode biner yang dalam hal ini untuk karakter komputer digunakan 5 bit untuk menyimpan informasi masing-masing karakter yang digunakan.

\subsection{Sistem Pembelajaran}

Sistem kedua adalah sistem pembelajaran. Sistem pembangun utama dari sistem pembelajaran ini adalah jaringan saraf Tiruan Backpropagation.

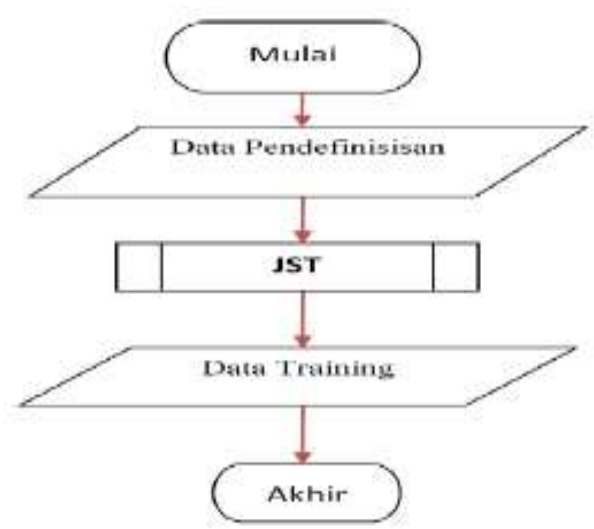

Gambar 5. Struktur Kerja Sistem Pembelajaran.

Data pendefinisian adalah data yang diperoleh dari sistem pendefinisian. Node input diambil dari nilai piksel pada citra yang telah ditransformasi menjadi berukuran 9x9 piksel, yaitu 81 bit + 1 node bias. Sedangkan node output terdiri 5 node yang mewakili kode masing-masing karakter.

Dalam penelitian ini jumlah node tersembunyi dijadikan variabel yang akan diamati. Pemilihan jumlah node tersembunyi dapat dilakukan secara acak untuk mendapatkan hasil yang optimal. Dalam penelitian ini digunakan 20000 epoh/iterasi dalam proses pelatihan dengan nilai error sebesar 0.00001. Nilai setiap neutron selanjutnya disimpan untuk digunakan pada proses pendeteksian. 


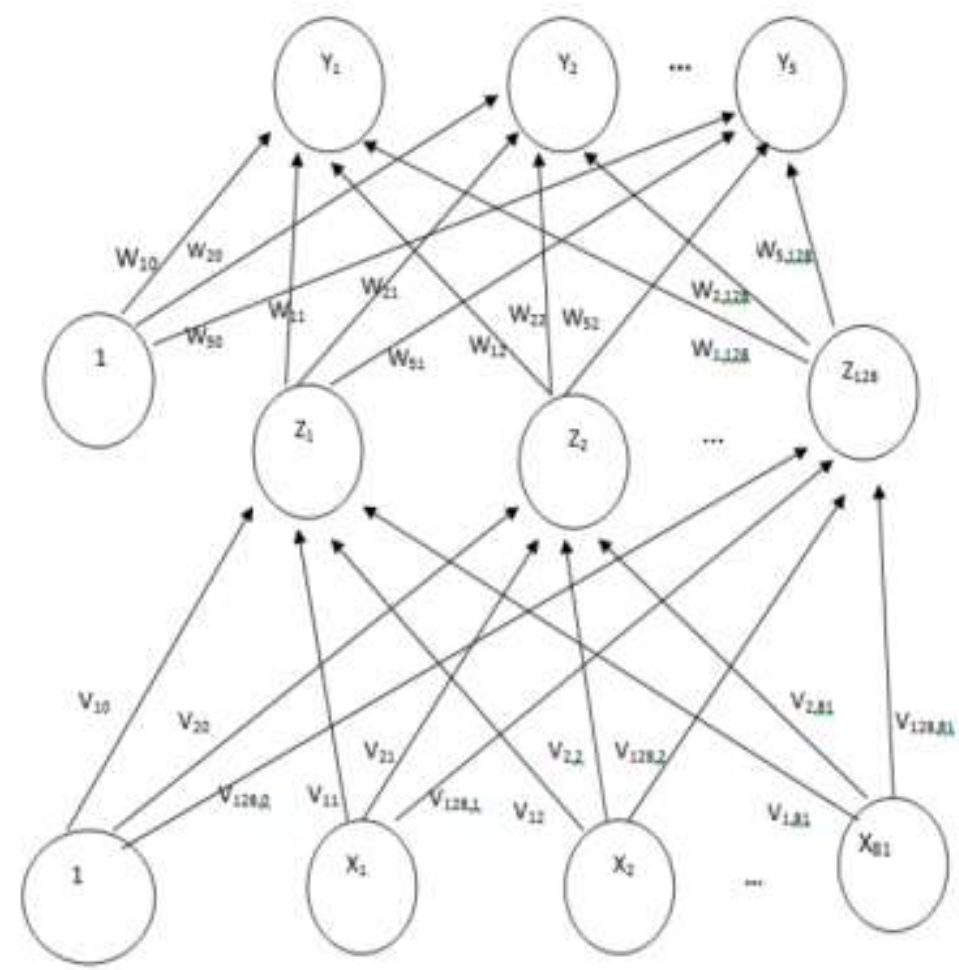

Gambar 6. Arsitektur JST pada Sistem Pembelajaran.

\subsection{Sistem Pendeteksian}

Sistem ketiga adalah sistem pendeteksian atau implementasi. Sistem ini dibangun dengan struktur seperti yang ditunjukkan pada Gambar 7. Proses yang ada dalam sistem ini merupakan gabungan dari sistem pendefinisian dan sistem pembelajaran.

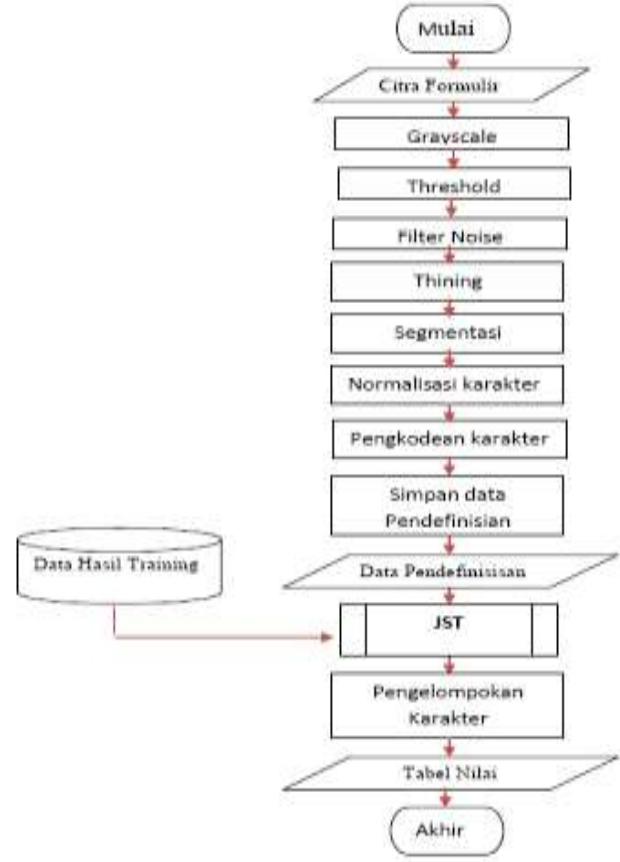

Gambar 7. Struktur Kerja Sistem Pendeteksian. 
Pada sistem pendeteksian, bobot pada JST diperoleh dari data hasil training pada proses pembelajaran. Pada bagian akhir sistem pendeteksian, karakter yang ada dikelompokkan berdasarkan jenisnya yaitu semester, kode matakuliah, program studi, nim mahasiswa dan nilai. Informasi pengelompokan ini didasarkan pada pengetahuan yang diberikan kedalam sistem tentang lokasi masing-masing komponen data tersebut. Selanjutnya hasil ini disimpan ke dalam database.

\section{Pengujian Sistem}

Dari hasil pengujian yang diberikan pada 4 buah formulir nilai seperti yang ditunjukkan pada lampiran dengan beberapa jumlah node layer tersembunyi diperoleh hasil seperti yang ditunjukkan Tabel 1 berikut.

Tabel 1. Hasil Pengujian.

\begin{tabular}{ccccc}
\hline \multirow{2}{*}{$\begin{array}{c}\text { Jumlah Node Layer } \\
\text { Tersembunyi }\end{array}$} & \multicolumn{4}{c}{ Persentase Kesalahan } \\
\cline { 2 - 5 } & $\begin{array}{c}\text { Formulir } \\
\text { Pertama }\end{array}$ & $\begin{array}{c}\text { Formulir } \\
\text { Kedua }\end{array}$ & $\begin{array}{c}\text { Formulir } \\
\text { Ketiga }\end{array}$ & $\begin{array}{c}\text { Formulir } \\
\text { Keempat }\end{array}$ \\
\hline 5 & $1.78 \%$ & $3.56 \%$ & $1.78 \%$ & $0.90 \%$ \\
20 & $1.34 \%$ & $0.44 \%$ & $0.44 \%$ & $0.45 \%$ \\
30 & $1.34 \%$ & $2.22 \%$ & $1.78 \%$ & $0.90 \%$ \\
40 & $1.34 \%$ & $2.67 \%$ & $1.33 \%$ & $0.90 \%$ \\
50 & $1.34 \%$ & $2.22 \%$ & $1.78 \%$ & $0.90 \%$ \\
80 & $1.34 \%$ & $2.67 \%$ & $1.33 \%$ & $0.90 \%$ \\
100 & $11.61 \%$ & $12.44 \%$ & $11.56 \%$ & $11.26 \%$ \\
110 & $0.89 \%$ & $0.78 \%$ & $0.44 \%$ & $2.25 \%$ \\
120 & $0.89 \%$ & $0.44 \%$ & $0.44 \%$ & $0.45 \%$ \\
128 & $0.00 \%$ & $0.00 \%$ & $0.00 \%$ & $0.00 \%$ \\
140 & $0.89 \%$ & $2.67 \%$ & $0.89 \%$ & $2.70 \%$ \\
150 & $1.34 \%$ & $2.22 \%$ & $0.89 \%$. & $0.9 \%$ \\
\hline
\end{tabular}

Berdasarkan hasil pengujian terlihat bahwa penggunaan layer tersembunyi disekitar angka 110128 memberikan hasil yang lebih baik. Berdasarkan hasil penelitian tersebut pada kondisi jumlah layer tersembunyi sebanyak 128 diperoleh hasil semua citra tanpa kesalahan pembacaan.

\section{Kesimpulan dan Saran}

\subsection{Kesimpulan}

1. Penerapan jaringan syaraf tiruan pada pembacaan formulir nilai matakuliah dilakukan dengan mengenali setiap karakter berdasarkan struktur tulangnya yang diperoleh dari operasi thinning. Karakter yang diperoleh selanjutnya ditransformasi kedalam ukuran 9x9 piksel sebagai input node pada jaringan syaraf tiruan. 
2. Untuk membatasi output yang mungkin dari sistem yang dibangun, node output pada jaringan menggunakan 5 node yang mewakili kode karakter yang digunakan.

3. Hasil penelitian menunjukkan bahwa jumlah node layer tersembunyi sangat menentukan akurasi pengenalan yang dilakukan oleh sistem.

4. Jumlah node tersembunyi yang sebaiknya digunakan untuk sistem ini adalah 128 node karena menghasilkan persentasi terkecil dari keempat citra uji.

\subsection{Saran}

1. Untuk meningkatkan akurasi pengenalan karakter, jumlah karakter pelatihan harus ditingkatkan.

2. Untuk mengurangi kesalahan akibat berbedanya ukuran huruf, maka perlu dipikirkan algoritma transformasi yang lebih baik.

\section{Daftar Pustaka}

Darmaputra, 2003, "Binerisasi citra dengan metode Otsu", Website: http://ejournal.unud.ac.id/ abstrak/darmaputra_3_.pdfs, diakses Agustus 2009.

Kamruzzaman, Joarder, dan Aziz, S.M., 1998. "A neural network based character recognition system using double Backpropagation”, Malaysian Journal of Computer Science, Vol. 11 No. 1.

Lyanthi, M., 2003. Pengolahan citra. Website: http://ifunpas.org/downloads/Handout/MateriDiKelasPC/Pertemuan1_Pendahuluan.pdf, diakses Agustus 2009.

Siang, J.J., 2005. Jaringan Syaraf Tiruan dan Pemprogramanya Menggunakan Matlab. Penerbit Andi, Yogyakarta.

Wibowo, E. dan Kurniawan, E., 2004. Konvolusi. Sumber:

http://www2.ukdw.ac.id/kuliah/si/erickblog/MatakuliahKomputerGrafis_10E92/ 06Konvolusi.pdf, diakses November 2009. 